EXPERIMENTAL STUDY

\title{
Interactions of insulin-like growth factor-I, insulin and estradiol with GnRH-stimulated luteinizing hormone release from female rat gonadotrophs
}

\author{
Y-X Xia ${ }^{1,2}$, J-M Weiss ${ }^{1}$, S Polack ${ }^{1}$, K Diedrich $^{1}$ and O Ortmann ${ }^{1}$ \\ ${ }^{1}$ Department of Obstetrics and Gynecology, Medical University of Lübeck, Lübeck, Germany and ${ }^{2}$ Women's Hospital, School of Medicine Zhejiang \\ University, Hangzhou, China \\ (Correspondence should be addressed to O Ortmann, Department of Obstetrics and Gynecology, Medical University of Lübeck, Ratzeburger Allee 160, \\ 23538 Lübeck, Germany; E-mail: ortmann@medinf.mu-luebeck.de)
}

\begin{abstract}
Background: It is well established that ovarian steroids modulate gonadotropin secretion from anterior pituitary cells. It has been speculated that insulin and IGF-I might influence gonadotropin secretion. Objective: To investigate the effects of IGF-I and estradiol alone, or combinations of IGF-I with insulin and estradiol on GnRH-stimulated LH release from female rat pituitary cells in serum-supplemented and serum-free culture conditions.

Methods: Pituitary cells were incubated for $24 \mathrm{~h}$ or $48 \mathrm{~h}$ with a series of increasing concentrations of IGF-I or estradiol and stimulated with $1 \mathrm{nmol} / \mathrm{l} \mathrm{GnRH}$ for $3 \mathrm{~h}$. To determine the interaction of IGF-I and estradiol on GnRH-stimulated LH secretion, cells were exposed to increasing concentrations of IGF-I and $100 \mathrm{pmol} / \mathrm{l}$ estradiol for $24 \mathrm{~h}$. We also investigated the effects of combined treatment with IGF-I and insulin on GnRH-stimulated LH secretion.

Results: Our findings indicate that long-term IGF-I treatment $(24 \mathrm{~h})$ alone has a significant augmenting effect on GnRH-stimulated LH release in serum-free medium only, with a maximum at low concentrations (10 and $100 \mathrm{pmol} / \mathrm{l})$. Estradiol significantly increased GnRH-induced LH release in a dose-dependent manner. The extent of GnRH-stimulated LH secretion by long-term estradiol treatment $(24 \mathrm{~h})$ was significantly greater in serum-supplemented $(+42 \%)$ medium than in serumfree medium. Estradiol facilitated IGF-I-primed LH responses to GnRH in serum-free medium. In contrast, in serum-supplemented medium, the facilitating potential of estradiol was lower. We also found that, in GnRH-stimulated cells, LH release was augmented by insulin treatment, in contrast to quiescent cells that had been pretreated with $100 \mathrm{pmol} / \mathrm{l}$ IGF-I alone and $1 \mathrm{nmol} / \mathrm{l}$ insulin alone. Conclusions: IGF-I and to a lesser extent insulin stimulate GnRH-induced LH secretion from pituitary gonadotrophs. This action is enhanced by estradiol treatment of the cells. However, the well known stimulatory action of estradiol on LH secretion is dependent on the presence of growth factors.
\end{abstract}

European Journal of Endocrinology 144 73-79

\section{Introduction}

Gonadotropin releasing hormone $(\mathrm{GnRH})$ is the primary regulator of luteinizing hormone (LH) secretion from pituitary gonadotrophs. LH secretion is controlled by gonadal steroid hormones through positive and negative feedback regulation (1-3). Insulin-like growth factor-I (IGF-I) may also be involved in the regulation of LH secretion (4).

IGF-I is a 70 amino acid mitogenic polypeptide that shares $43 \%$ amino acid sequence homology with insulin and induces cellular differentiation and promotes the expression of differentiated functions in a variety of cells $(5,6)$. Recent studies demonstrate that IGF-I mRNA and receptors of IGF-I (IGFR-I) are widely synthesized and distributed in cells of mesenchymal origin, including uterus, ovaries and the pituitary gland $(5,7,8)$. IGF-I is believed to function through an endocrine or paracrine-autocrine mechanism, or both. Numerous reports describe the effects of IGF-I at the level of the ovary (9-16). IGF-I is able to enhance LH- or human chorionic gonadotropin-stimulated androgen release, follicle-stimulating hormone (FSH)induced steroidogenesis, and promotes the growth and differentiation of ovarian cells. Increased activity of IGF-I is involved in the hypersensitivity of the ovaries of patients with polycystic ovary syndrome to endogenous and exogenous gonadotropins. However, the role of IGF-I in the regulation of LH secretion is not yet clear. IGF-I increases GnRH secretion from the eminentia 
media of the rat in vitro. Ethanol suppresses hepatic IGF-I mRNA levels in vivo, with a subsequent and concomitant decrease in the circulating concentrations of IGF-I and LH $(17,18)$, indicating a possible linkage between IGF-I and LH secretion. The findings of recent studies suggest a correlation between serum concentrations of IGF-I and estradiol: estradiol treatment leads to an increase in serum IGF-I concentration in mature cows (19), gilts (20) and ewes (21), whereas it suppresses serum IGF-I concentration in the rat (22). Transdermal estradiol patches in postmenopausal women increase serum IGF-I concentrations; oral administration, however, results in reduced serum IGF-I concentrations (23), and serum IGF-I concentrations were significantly increased in the preovulatory phase in normal women (24). Wilson (25) reported that, in female monkeys, the sensitivity to estradiol feedback inhibition of serum LH was regulated by serum concentrations of IGF-I. Clapper et al. (21) demonstrated that reduced concentrations of circulating LH were accompanied by increased concentrations of IGF-binding proteins (IGFBPs) in the pituitary of estradiol-treated ovariectomized ewes. There is accumulating evidence that estradiol indirectly regulates the synthesis and secretion of LH through alteration of IGF-I action. These findings suggest that IGF-I might be a candidate target of estromedin $(26,27)$, and furthermore, it might contribute to the modulation of LH secretion by the anterior pituitary.

A limited amount of data indicate that IGF-I is able to increase LH release from male rat pituitary cells $(4,28)$. In the present study, we investigated the actions of IGF-I and insulin on LH secretion from female rat pituitary cells. In addition, we characterized the interactions of IGF-I, insulin and estradiol on GnRH-stimulated LH release.

\section{Materials and methods}

\section{Pituitary cell preparation and culture conditions}

Pituitary glands were obtained from adult (200-300 g) female Sprague-Dawley rats (Charles River, Kirchborchen, Germany) at random stages of the estrous cycle. Single-cell suspensions were prepared by controlled trypsinization as described previously (29). Briefly, anterior pituitaries were minced into small pieces. After digestion with $0.5 \%$ trypsin, they were treated with DNAse and $0.1 \%$ trypsin inhibitor. After gentle pipetting, dispersed cells were collected by centrifugation. Cell viability was determined using trypan blue exclusion method (usually more than 95\%).

Pituitary cells were cultured on multiwell dishes (200 000 cells/well) in medium 199 with Hanks' salts and L-glutamine, supplemented with $1.4 \mathrm{~g} / \mathrm{l}$ sodium bicarbonate, $10 \mu \mathrm{g} / \mathrm{ml}$ streptomycin, $100 \mathrm{U} / \mathrm{ml}$ penicillin and $10 \%$ horse serum pretreated with $2 \%$ charcoal (Norit A) and 0.2\% Dextran T 70 (Pharmacia, Uppsala, Sweden) (incubation medium). To allow cell attachment, cells were kept for $36 \mathrm{~h}$ in humidified incubators at $37{ }^{\circ} \mathrm{C}$ in an atmosphere of $5 \% \mathrm{CO}_{2}$ and $95 \%$ air.

\section{Treatment of cultured pituitary cells}

After cell attachment, IGF-I, insulin (both dissolved in acidified PBS) and estradiol (dissolved in ethanol; all Sigma, St Louis, MO, USA), were added to the culture medium at appropriate concentrations for $24-48 \mathrm{~h}$. The final concentration of ethanol in the culture medium was $0.2 \%$. Controls were exposed to phenolred-free medium 199 (Biochrom, Berlin, Germany), which was used in all cultures, containing the same quantity of ethanol, PBS, or both, without hormones (vehicle). For certain experiments, cells were incubated in serum-free media after the attachment period for up to $48 \mathrm{~h}$. Their viability was not influenced as determined by the trypan blue exclusion method.

Before the cells were stimulated with GnRH, they were washed with serum-free medium $(0.3 \%$ BSA instead of $10 \%$ horse serum) and incubated for $20 \mathrm{~min}$. Then the medium was renewed and GnRH was directly added to culture media. After incubation for $3 \mathrm{~h}$, the medium was collected and stored at $-20{ }^{\circ} \mathrm{C}$. All experiments were performed in triplicate and repeated three or four times.

\section{Effects of IGF-I on LH secretion from pituitary cells cultured in serum-supplemented or serum-free medium}

In the first series of experiments, we intended to determine the effects of serum on IGF-I actions in gonadotrophs. For this purpose, pituitary cells were incubated for $24 \mathrm{~h}$ and $48 \mathrm{~h}$ with a series of increasing concentrations of IGF-I (10 and $100 \mathrm{pmol} / \mathrm{l}, 1$ and $10 \mathrm{nmol} / \mathrm{l}$ ) in serum-supplemented or serum-free medium and stimulated with $1 \mathrm{nmol} / \mathrm{l} \mathrm{GnRH}$ during the last $3 \mathrm{~h}$ of incubation.

\section{Effects of estradiol on LH secretion from pituitary cells cultured in serum- supplemented or serum-free medium}

To determine the influence of serum on the effects of estradiol on LH secretion, pituitary cell cultures were incubated with serum-supplemented or serum-free media and treated with increasing concentrations of estradiol (1, 10 and $100 \mathrm{pmol} / \mathrm{l}, 1,10$ and $100 \mathrm{nmol} / \mathrm{l})$ for $24 \mathrm{~h}$, and finally stimulated with $1 \mathrm{nmol} / \mathrm{l} \mathrm{GnRH}$ during the last $3 \mathrm{~h}$ of the incubation periods. 


\section{Interactions of IGF-I and estradiol on LH secretion from pituitary cells cultured in serum-supplemented or serum-free medium}

To clarify the possible interactions between IGF-I and estradiol, pituitary cells were treated in serum-supplemented or serum-free medium and exposed to $100 \mathrm{pmol} / \mathrm{l}$ IGF-I, $100 \mathrm{pmol} / \mathrm{l}$ estradiol alone and combinations of increasing concentrations of IGF-I (10 and $100 \mathrm{pmol} / \mathrm{l}, 1$ and $10 \mathrm{nmol} / \mathrm{l}$ ) and $100 \mathrm{pmol} / \mathrm{l}$ estradiol for $24 \mathrm{~h}$. During the last $3 \mathrm{~h}$ of incubation periods cells were stimulated with $1 \mathrm{nmol} / \mathrm{l} \mathrm{GnRH}$.

\section{Interactions of IGF-I and insulin on LH secretion from pituitary cells in serum-free medium}

To investigate the interactions between IGF-I and insulin pituitary cells were incubated in serum-free medium with $100 \mathrm{pmol} / \mathrm{l}$ IGF-I, $1 \mathrm{nmol} / \mathrm{l}$ insulin and combinations of increasing concentrations of IGF-I (10 and $100 \mathrm{pmol} / \mathrm{l}, 1$ and $10 \mathrm{nmol} / \mathrm{l}$ ) and $1 \mathrm{nmol} / \mathrm{l}$ insulin for $48 \mathrm{~h}$.

Another group of cells was treated with $1 \mathrm{nmol} / \mathrm{l}$ insulin for $48 \mathrm{~h}$, overlapped by $100 \mathrm{pmol} / \mathrm{l}$ IGF-I treatment for the last $24 \mathrm{~h}$. Finally cells were stimulated with $1 \mathrm{nmol} / \mathrm{l} \mathrm{GnRH}$ during the last $3 \mathrm{~h}$ of incubation.

\section{Radioimmunassay and data analysis}

The content of the samples was analyzed by radioimmuoassay, using the reference preparation RP-3 rat LH provided by the National Hormone and Pituitary Program (Baltimore, MD, USA). The intra- and interassay coefficients of variation were less than $5 \%$.

Data obtained from three or four experiments, each run in triplicate, were pooled and expressed as percentage of control cells $(100 \%)$. Statistically significant differences between treatments were determined by one-factor analysis of variance (ANOVA), followed by Dunnett's post-hoc test. $P$ values less than 0.05 were considered statistically significant.

\section{Results}

\section{Effects of serum and IGF-I on LH secretion from gonadotrophs}

IGF-I treatments did not change basal or GnRHinduced LH secretion from pituitary cells cultured in serum-supplemented media (data not shown). In contrast, cells that were incubated in serum-free medium responded with enhanced LH release to GnRH stimulation when they had been pretreated for $24 \mathrm{~h}$ or $48 \mathrm{~h}$ with IGF-I. This effect was statistically significant at concentrations of IGF-I between 10 and $100 \mathrm{pmol} / \mathrm{l}$ after $24 \mathrm{~h}$ treatments (Fig. 1b). IGF-I (a) Basal

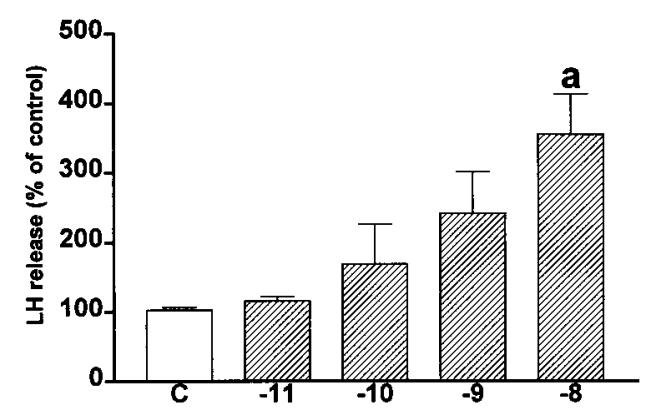

Log IGF-I concentration (M)

(b) $1 \mathrm{nM} \mathrm{GnRH}$

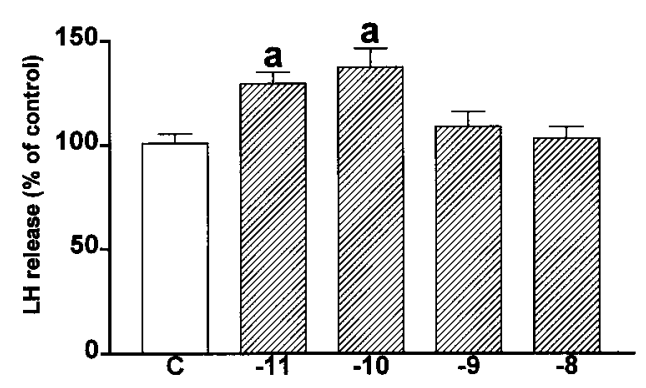

Log IGF-I concentration (M)

Figure 1 Effects of increasing concentrations of IGF-I on (a) basal and $(b) \mathrm{GnRH}$-induced $\mathrm{LH}$ release in serum-free medium. Pituitary cells were treated for $24 \mathrm{~h}$ with IGF-I in concentrations of $10 \mathrm{pmol} / \mathrm{l}$ to $10 \mathrm{nmol} / \mathrm{l}$ and then stimulated for $3 \mathrm{~h}$ with $1 \mathrm{nmol} / \mathrm{GnRH}$. The data from four independent experiments, each run in triplicate, were pooled (mean \pm S.E.M.) and are expressed as percentage of control $(\mathrm{C}) .{ }^{\mathrm{a}} P<0.05$ compared with $\mathrm{C}$.

induced a dose-dependent stimulatory action on basal LH secretion from cells cultured in serum-free medium (Fig. 1a). Maximum response $(+250 \%)$ was found with $10 \mathrm{nmol} / \mathrm{l}$ IGF-I.

\section{Effects of serum and estradiol on LH secretion from gonadotrophs}

Estradiol led to a significant enhancement of basal or GnRH-stimulated LH responses in serum-supplemented medium (Fig. 2). Greatest concentrations of LH were found with estradiol $10 \mathrm{pmol} / \mathrm{l}$ for stimulated and $100 \mathrm{pmol} / \mathrm{l}$ for basal LH production. In serum-free medium, however, estradiol did not alter basal or GnRH-induced LH secretion (data not shown). Thus the amount of basal or GnRH-stimulated LH release after pretreatment with estradiol in serum-supplemented 
(a)

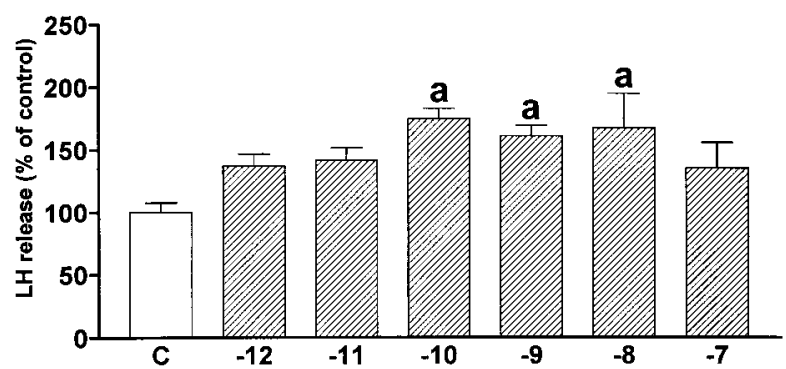

Log Estradiol concentration (M)

(b)

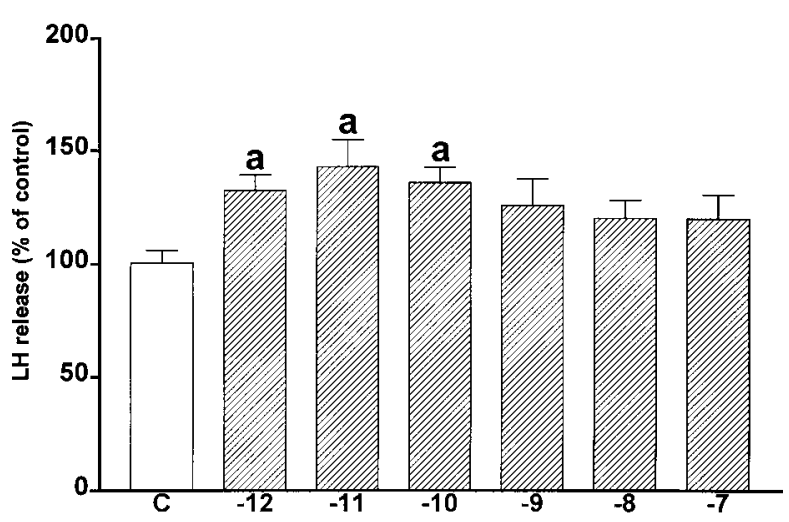

\section{Log Estradiol concentration (M)}

Figure 2 Effects of increasing concentrations estradiol on (a) basal and (b) GnRH-induced LH release in serumsupplemented medium. Pituitary cells were treated for $24 \mathrm{~h}$ with estradiol in concentrations from $1 \mathrm{pmol} / \mathrm{l}$ to $100 \mathrm{nmol} / \mathrm{l}$ and then stimulated for $3 \mathrm{~h}$ with $1 \mathrm{nmol} / \mathrm{l} \mathrm{GnRH}$. The data from four independent experiments, each run in triplicate, were pooled (mean \pm S.E.M.) and are expressed as percentage of control (C). ${ }^{a} P<0.05$ compared with $\mathrm{C}$.

medium was significantly greater than that in serumfree medium $(P<0.05)$.

\section{Additive effects of IGF-I and estradiol on LH secretion from gonadotrophs in different serum conditions}

In serum-free medium, the combination of IGF-I and estradiol led to a significantly greater basal and GnRHstimulated LH secretion compared with either estradiol or IGF-I treatment alone $(P<0.05)$. We observed this for all four different concentrations of IGF-I (10 pmol/l to $10 \mathrm{nmol} / \mathrm{l}$ ) combined with $100 \mathrm{pmol} / \mathrm{l}$ estradiol after (a)

Basal

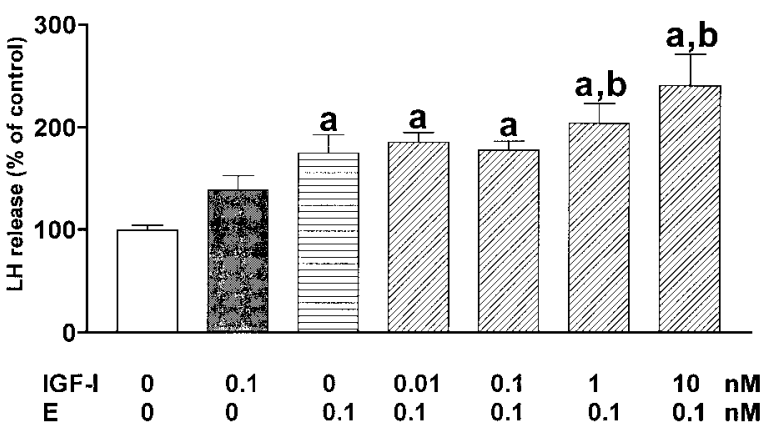

(b)

\section{$1 \mathrm{nM} \mathrm{GnRH}$}

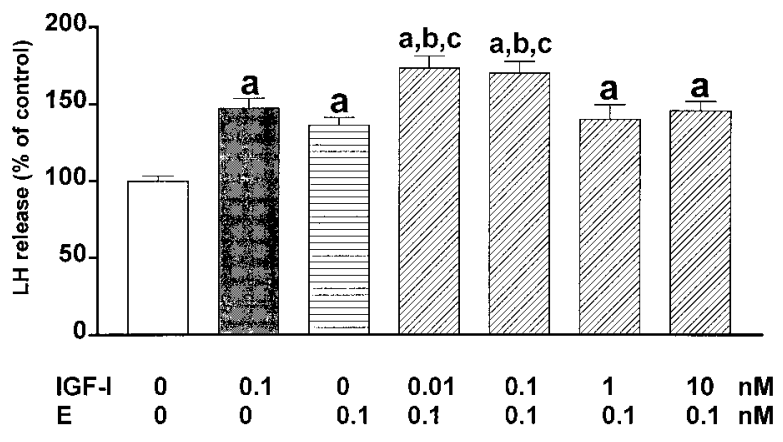

Figure 3 Effects of combined treatment with IGF-I and estradiol (E) on (a) basal and (b) $\mathrm{GnRH}$-induced $\mathrm{LH}$ release in serum-free medium. Pituitary cells were treated for $24 \mathrm{~h}$ with $100 \mathrm{pmol} / \mathrm{I}$ IGF-I, $100 \mathrm{pmol} / \mathrm{l}$ estradiol or combinations of IGF-I (in the range $10 \mathrm{pmol} / \mathrm{I}$ to $10 \mathrm{nmol} / \mathrm{l})$ and estradiol $(100 \mathrm{pmol} / \mathrm{l})$ and then stimulated for $3 \mathrm{~h}$ with $1 \mathrm{nmol} / \mathrm{l} \mathrm{GnRH}$. The data from four independent experiments, each run in triplicate, were pooled (mean \pm S.E.M.) and are expressed as percentage of control (0). ${ }^{a} P<0.05$ compared with control; ${ }^{b} P<0.05$ compared with IGF-I; ${ }^{c} P<0.05$ compared with estradiol.

a 24-h incubation period. Lower concentrations of IGFI (10 and $100 \mathrm{pmol} / \mathrm{l})$ were most effective (Fig. 3).

In contrast, in serum-supplemented medium, all four different concentrations of IGF-I and estradiol did not change the LH secretion compared with control and with either estradiol or IGF-I alone (data not shown).

\section{Additive effects of IGF-I and insulin on LH secretion from gonadotrophs in serum-free medium}

The combination of insulin and IGF-I led to a greater GnRH-stimulated secretion of LH compared with that produced with IGF-I or insulin treatment alone. Although the exposure of pituitary cells to $100 \mathrm{pmol} / \mathrm{l}$ IGF-I for $48 \mathrm{~h}$ and $1 \mathrm{nmol} / \mathrm{l}$ insulin for $24 \mathrm{~h}$ in serum-free medium led to a significant increase in GnRH-stimulated 
(a)

\section{$1 \mathrm{nM}$ GnRH}

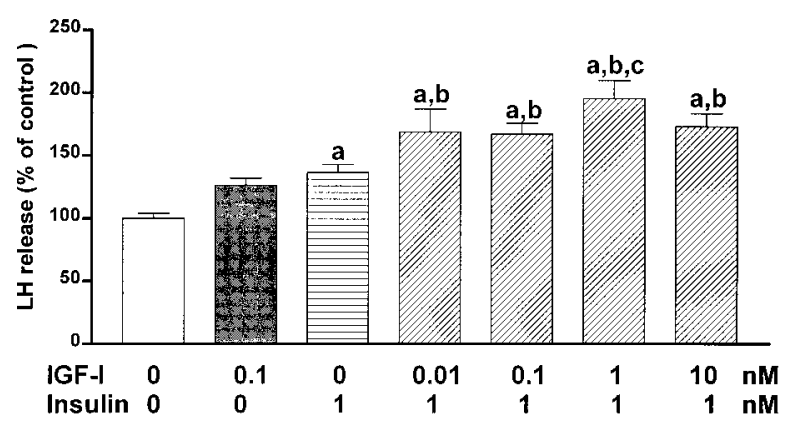

(b)

\section{$1 \mathrm{nM}$ GnRH}

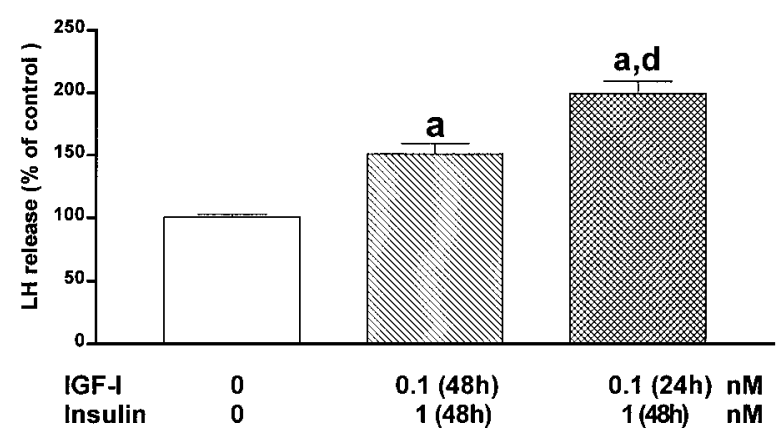

Figure 4 Effects of combined treatment with IGF-I and insulin on $\mathrm{GnRH}$-induced $\mathrm{LH}$ release in serum-free medium. (a) Pituitary cells were treated for $48 \mathrm{~h}$ with $100 \mathrm{pmol} / \mathrm{I}$ IGF-I, $1 \mathrm{nmol} / \mathrm{l}$ insulin or combinations of IGF-I (from $10 \mathrm{pmol} / \mathrm{I}$ to $10 \mathrm{nmol} / \mathrm{l}$ ) and $1 \mathrm{nmol} / \mathrm{I}$ insulin and then stimulated for $3 \mathrm{~h}$ with $1 \mathrm{nmol} / \mathrm{l} \mathrm{GnRH}$. The data from four independent experiments, each run in triplicate, were pooled (mean \pm S.E.M.) and are expressed as percentage of control (0). ${ }^{\text {a }} P<0.05$ compared with control; ${ }^{b} P<0.05$ compared with IGF-I; ${ }^{c} P<0.05$ compared with insulin. (b) Cells were treated with $1 \mathrm{nmol} / \mathrm{l}$ insulin for $48 \mathrm{~h}$, overlapped by $100 \mathrm{pmol} / \mathrm{l}$ IGF-I for the last $24 \mathrm{~h}$, and stimulated with $1 \mathrm{nmol} / \mathrm{l} \mathrm{GnRH}$ during the last $3 \mathrm{~h}$. ${ }^{a} P<0.001$ compared with control; ${ }^{d} P<0.001$ compared with insulin plus IGF-I (48 h).

LH release ( $126 \%$ and $136 \%$ respectively), even greater amounts of GnRH-stimulated LH secretion $(166 \%$ to $195 \%)$ were observed when $1 \mathrm{nmol} / \mathrm{l}$ or $100 \mathrm{pmol} / \mathrm{l}$ insulin and $1 \mathrm{nmol} / \mathrm{l}$ IGF-I treatments were combined $(P<0.05$; Fig. 4a).

The maximal effect on LH secretion (200\%) resulted from treatment with $1 \mathrm{nmol} / \mathrm{l}$ insulin for $48 \mathrm{~h}$ overlapped by $100 \mathrm{pmol} / \mathrm{l}$ IGF-I for the last $24 \mathrm{~h}$ (Fig. $4 b$ ).

\section{Discussion}

In this study we have demonstrated a facilitatory action of IGF-I on GnRH-induced LH secretion. The IGF-I effects occurred in serum-free culture conditions and with low concentrations of IGF-I. Furthermore, additive actions of IGF-I with estradiol and insulin have been characterized.
Similar to the GnRH receptor, the IGF-I receptor also undergoes receptor internalization and perhaps undergoes downregulation in response to high concentrations of the ligand $(20,30)$. The extent of ligand-mediated down-regulation depends primarily upon the amount of ligand to which the cells are exposed. This may, in part, explain the LH response to low, but not to high concentrations of IGF-I.

Enhancement of LH secretion was observed only under serum-free culture conditions. The presence of serum constituents might have an inhibitory effect on the function of gonadotrophs (31). Soldani et al. (28) demonstrated a marked reduction of GnRH-stimulated LH release by an antibody against IGF-I. This seems to indicate that, in serum-supplemented culture conditions, a relevant component of the LH response to GnRH is due to the presence of IGF-I. This may partially explain the increase of LH secretion in IGF-I-treated cells in serum-free medium, but not in serum-supplemented medium. To eliminate the in vivo regulation of growth hormone-IGF-I and to clarify the role of IGF-I per se, we conducted the experiments in vitro in serumfree culture conditions.

Our results are in partial agreement with those of others $(4,20,28,32,33)$ who found that IGF-I stimulated basal LH release or enhanced the $\mathrm{LH}$ response to GnRH (or both), in male rat, pig and fish pituitary cells in vitro. In the present study, the concentrations of IGF-I that were able to affect GnRHstimulated LH release significantly were different from those in the other studies. Variations in results from individual investigations might be due to the difference in animal strains, endocrine environment (female or male rats; prepubertal, adult or ovariectomized rats), estrous cycle, and other experimental conditions.

The mechanism of the actions of IGF-I on GnRHstimulated LH release at the level of the pituitary remain unclear. Kanematsu et al. (32) reported that anti-IGF-I receptor antibody suppressed the effect of IGF-I on GnRH-stimulated LH release, suggesting that IGF-I that is produced in an autocrine or paracrine manner stimulates the secretion of LH at least partially via IGF-I receptors.

The sensitivity of IGF-I in the pituitary might be influenced by the reproductive status (20). Here, we demonstrated that estradiol treatment significantly enhanced GnRH-stimulated LH secretion in serumsupplemented medium, indicating an additive effect with IGF-I that is present in serum. The magnitude of the GnRH-stimulated LH secretion after treatment with estradiol in serum-free medium was much lower than that in serum-supplemented medium.

Recent in vivo studies suggest steroid regulation of serum IGF-I concentrations. Estradiol treatment increased serum concentrations of IGF-I that were decreased after ovariectomy in mature cows (19), gilts (20) and ewes (21). However, in the rat (22), ovariectomy increased serum IGF-I concentrations, 
and estradiol treatment suppressed serum IGF-I concentrations. Ovesen et al. (24) reported that serum IGFI concentrations were significantly increased in the preovulatory phase in normal women, which is in contrast to the findings of other recent studies that demonstrated no change in serum IGF-I concentrations throughout the menstrual cycle $(6,34)$. The mechanisms underlying this apparent divergence in IGF-I responses after exogenous or endogenous increase in estradiol concentrations remain unclear.

Our findings indicate that there are interactions between IGF-I and estradiol at the pituitary level. The mechanism of such synergism on GnRH-stimulated LH secretion is still unclear, but several possibilities have been considered. Michels et al. (7) reported that estradiol had prominent effects on components of the IGF system in the anterior pituitary, and that IGF-I mRNA, IGF-I binding and IGFBPs in the rat pituitary gland were increased by estradiol treatment. The greatest levels of pituitary IGF-I binding and IGFBP-1 expression could be demonstrated at proestrus in the rat - a time when serum concentrations of estradiol are greatest. The findings of the present study, together with these previous observations, suggest that estradiol alters the pituitary responsiveness to IGF-I. This supports the possibility that the amount of IGF-I receptor varies throughout the estrous cycle and pituitary IGF-I receptors are also regulated by estradiol (20). Changes in pituitary IGF-I receptor numbers could partially explain the estradiol modulation of IGFI-induced LH secretion described in this study, suggesting a possible role for pituitary IGF-I as a mediator of the effects of estradiol on the pituitary.

Recently a study by Sugino et al. (27) indicated that this synergistic effect involves, at least in part, IGF-Istimulated estradiol receptor mRNA expression. Therefore, IGF-I may also sensitize pituitary cells to estradiol action by upregulating estradiol receptor expression. This might explain in part the observation that IGF-I and estradiol together facilitate the modulation of $\mathrm{LH}$ secretion. The results also indicate that there is a feedback mechanism between IGF-I and estradiol. The steroid downregulates the concentration of the IGF-I receptor and its ligand (27). Therefore, synergistic actions of IGF-I and estradiol on GnRH-stimulated LH secretion might occur predominantly at low concentrations of IGF-I, as observed in the present study.

There are close interactions between IGF-I and insulin (13). IGF-I shares 43\% amino acid sequence homology with insulin, and biological activities of IGF-I are similar to those of insulin (35). Furthermore, insulin can bind to IGF-I receptors, although with low affinity, and IGF-I at high concentrations can also bind to insulin receptors (6). Moreover, IGF-I $(4,20,28,33)$ and insulin $(4,31)$ are able to enhance basal and GnRH-stimulated LH release in serum-free medium. Both, IGF-I receptors and insulin receptors are localized in rat pituitary glands $(8,36)$.
Our findings demonstrate that there are additive effects of IGF-I and insulin on GnRH-stimulated LH release at the pituitary level. A recent study has also shown that treatment with either IGF-I or insulin alone fails to increase the percentage of proliferation of pituitary cells, but combined treatment with IGF-I plus insulin shows a significant increase (35). This result suggests that low concentrations of insulin enhance the response of pituitary cells to IGF-I, whereas at high concentrations, insulin binds to IGF-I receptors to trigger cell proliferation. Therefore, the IGF-I receptor-mediated system and the insulin receptor-mediated system may work together in the regulation of pituitary growth processes and promotion of the expression of differentiated functions of the pituitary. Thus the effects of insulin on the pituitary cells might be mediated through IGF-I receptors (35). Mason et al. (37) reported that insulin and subsequent IGF-I preincubation enhanced both basal and FSH-induced release of estradiol from granulosa cells. The possible mechanism of this synergistic effect may be via increased expression of IGF-I receptor at the cell surface by insulin, similar to the findings with IGF-II (37).

In conclusion, the present study clearly demonstrates additive actions between IGF-I and estradiol to enhance GnRH-stimulated LH secretion from the female rat anterior pituitary cells. Furthermore, insulin enhanced the actions of IGF-I on secretory responses of gonadotrophs. These interactions may be responsible for the physiological regulation of gonadotropin secretion and certain pathophysiological conditions that are associated with hypersecretion of LH.

\section{References}

1 Ortmann O, Emons G, Knuppen R \& Catt KJ. Inhibitory actions of keoxifene on luteinizing hormone secretion in pituitary gonadotrophs. Endocrinology $1988 \mathbf{1 2 3} 962-968$.

2 Emons G, Hoffmann HG, Brack C, Ortmann O, Sturm R, Ball P et al. Modulation of gonadotropin-releasing hormone receptor concentration in cultured female rat pituitary cells by estradiol treatment. Journal of Steroid Biochemistry and Molecular Biology $198831751-756$.

3 Stojilkovic SS \& Catt KJ. Expression and signal transduction pathways of gonadotrophin-releasing hormone receptors. Recent Progress in Hormone Research 199550 161-205.

4 Soldani R, Cagnacci A \& Yen SS. Insulin, insulin-like growth factor I (IGF-I) and IGF-II enhance basal and gonadotrophinreleasing hormone-stimulated luteinizing hormone release from rat anterior pituitary cells in vitro. European Journal of Endocrinology $1994131641-645$.

5 Parmer TG, Roberts CT Jr, LeRoith D, Adashi EY, Khan I, Solan $\mathrm{N}$ et al. Expression, action, and steroidal regulation of insulin-like growth factor-I (IGF-I) and IGF-I receptor in the rat corpus luteum: their differential role in the two cell populations forming the corpus luteum. Endocrinology $1991 \mathbf{1 2 9} 2924-$ 2932.

6 Wang HS \& Chard T. IGFs and IGF-binding proteins in the regulation of human ovarian and endometrial function. Journal of Endocrinology $1999 \mathbf{1 6 1} 1-13$.

7 Michels KM, Lee WH, Seltzer A, Saavedra JM \& Bondy CA. Upregulation of pituitary $\left[{ }^{125} \mathrm{I}\right]$ insulin-like growth factor (IGF-I) 
binding and IGF binding protein-2 and IGF-I gene expression by estrogen. Endocrinology 1993132 23-29.

8 Bach MA \& Bondy CA. Anatomy of the pituitary insulin-like growth factor system. Endocrinology $19921312588-2594$.

9 Cara JF, Fan J, Azzarello J \& Rosenfield RL. Insulin-like growth factor I enhances luteinizing hormone binding to rat ovarian theca-interstitial cells. Journal of Clinical Investigation $1990 \mathbf{8 6}$ $560-565$.

10 Simone DA \& Mahesh VB. An autoregulatory process for androgen production in rat thecal-interstitial cells. Biology of Reproduction $1993 \mathbf{4 8} 46-56$.

11 Magoffin DA \& Weitsman SR. Effect of insulin-like growth factor I on cholesterol side-chain cleavage cytochrome P450 messenger ribonucleic acid expression in ovarian theca-interstitial cells stimulated to differentiate in vitro. Molecular and Cellular Endocrinology 199396 45-51.

12 Magoffin DA \& Weitsman SR. Insulin-like growth factor-I regulation of luteinizing hormone (LH) receptor messenger ribonucleic acid expression and LH-stimulated signal transduction in rat ovarian theca-interstitial cells. Biology of Reproduction $199451766-775$.

13 Campbell BK, Baird DT \& Webb R. Effects of dose of LH on androgen production and luteinization of ovine theca cells cultured in a serum-free system. Journal of Reproduction and Fertility 1998112 69-77.

14 Angervo M, Koistinen R, Suikkari AM \& Seppälä M. Insulin-like growth factor binding protein-I inhibits the DNA amplification induced by insulin-like growth factor I in human granulosaluteal cells. Human Reproduction 19916 770-773.

15 Kanzaki M, Hattori M \& Kojima I. Growth of differentiation: determination by FSH of the action of insulin-like growth factor-I in cultured rat granulosa cells. Endocrine Journal $19964315-$ 23.

16 LaVoie HA, Garmey JC \& Veldhuis JD. Mechanisms of insulin-like growth factor I augmentation of follicle-stimulating hormoneinduced porcine steroidogenic acute regulatory protein gene promotor activity in granulosa cells. Endocrinology 1999140 $146-153$.

17 Hiney JK, Srivastava V, Nyberg CL, Ojeda SR \& Dees WL. Insulinlike growth factor I of peripheral origin acts centrally to accelerate the initiation of female puberty. Endocrinology 1996 $1373717-3728$.

18 Hiney JK, Srivastava V, Lara T \& Dees WL. Ethanol blocks the central action of IGF-I to induce luteinizing hormone secretion in the prepubertal female rat. Life Sciences 199862 301-308.

19 Richards MW, Wettemann RP, Spicer LJ \& Morgan GL. Nutritional anestrus in beef cows: effects of body condition and ovariectomy on serum luteinizing hormone and insulin-like growth factor-I. Biology of Reproduction 1991 44 961-966.

20 Whitley NC, Barb CR, Utley RV, Popwell JM, Kraeling RR \& Rampacek GB. Influence of stage of the estrous cycle on insulinlike growth factor-I modulation of luteinizing hormone secretion in the gilt. Biology of Reproduction 199553 1359-1364.

21 Clapper JA, Snyder JL, Roberts AJ, Hanernik DL \& Moss GE. Estradiol increases relative amounts of insulin-like growth factor binding protein (IGFBP)-3 in serum and expression of IGFBP-2 in anterior pituitaries of ewes. Biology of Reproduction $1998 \mathbf{5 9}$ 124-130.

22 Krattenmacher R, Knauthe R, Parczyk K, Walker A, Hilgenfeldt U \& Fritzemeier KH. Estrogen action on hepatic synthesis of angiotensinogen and IGF-I: direct and indirect estrogen effects. Journal of Steroid Biochemistry and Molecular Biology $1994 \mathbf{4 8}$ 207-214.

23 Weissberger AJ, Ho KK \& Lazarus L. Contrasting effects of oral and transdermal routes of estrogen replacement therapy on $24-\mathrm{h}$ growth hormone (GH) secretion, insulin-like growth factor-I and GH-binding protein in post-menopausal women. Journal of Clinical Endocrinology and Metabolism 199172 374-381.

24 Ovesen P, Vahl N, Fisker S, Veldhuis JD, Christiansen JS \& Jorgensen JO. Increased pulsatile, but not basal, growth hormone secretion rates and plasma insulin-like growth factor I levels during the periovulatory interval in normal women. Journal of Clinical Endocrinology and Metabolism 199883 1662-1667.

25 Wilson ME. IGF-I administration advances the decrease in hypersensitivity to estradiol negative feedback inhibition of serum LH in adolescent female rhesus monkeys. Journal of Endocrinology 1995145 121-130.

26 Adesanya OO, Zhou J \& Bondy CA. Sex steroid regulation of insulin-like growth factor system gene expression and proliferation in primate myometrium. Journal of Clinical Endocrinology and Metabolism 199681 1967-1974.

27 Sugino N, Telleria CM, Tessier C \& Gibori G. Regulation and role of the insulin-like growth factor I system in rat luteal cells. Journal of Reproduction and Fertility 1999115 349-355.

28 Soldani R, Cagnacci A, Paoletti AM, Yen SS \& Melis GB. Modulation of anterior pituitary luteinizing hormone response to gonadotropin-releasing hormone by insulin-like growth factor I in vitro. Fertility and Sterility 199564 634-637.

29 Ortmann O, Sturm R, Knuppen R \& Emons G. Weak estrogenic activity of phenol red in the pituitary gonadotroph: re-evaluation of estrogen and antiestrogen effects. Journal of Steroid Biochemistry and Molecular Biology 199035 17-22.

30 Zapf A, Hsu D \& Olefsky JM. Comparison of the intracellular itineraries of insulin-like growth factor-I and insulin and their receptors in rat-I fibroblasts. Endocrinology 1994134 24452452.

31 Adashi EY, Hsueh AJ \& Yen SS. Insulin enhancement of luteinizing hormone and follicle-stimulating hormone release by cultured pituitary cells. Endocrinology 1981108 1441-1449.

32 Kanematsu T, Irahara M, Miyake T, Shitsukawa K \& Aono T. Effect of insulin-like growth factor I on gonadotropin release from the hypothalamus-pituitary axis in vitro. Acta Endocrinologica $1991125227-233$.

33 Weil C, Carre F, Blaise O, Breton B \& Le Bail PY. Differential effect of insulin-like growth factor I on in vitro gonadotropin (I and II) and growth hormone secretions in rainbow trout (Oncorhynchus mykiss) at different stages of the reproductive cycle. Endocrinology 1999140 2054-2062.

34 Thierry van Dessel HJ, Chandrasekher Y, Yap OW, Lee PD, Hintz RL, Faessen Gh et al. Serum and follicular fluid levels of insulin-like growth factor I (IGF-I), IGF-II, and IGF-binding protein-1 and -3 during the normal menstrual cycle. Journal of Clinical Endocrinology and Metabolism 199681 1224-1231.

35 Oomizu S, Takeuchi S \& Takahashi S. Stimulatory effect of insulin-like growth factor I on proliferation of mouse pituitary cells in serum-free culture. Journal of Endocrinology $1998 \mathbf{1 5 7}$ 53-62.

36 Unger JW \& Lange W. Insulin receptors in the pituitary gland: morphological evidence for influence on opioid peptide-synthesizing cells. Cell Tissue Research 1997288 471-483.

37 Mason HD, Willis DS, Holly JM \& Franks S. Insulin preincubation enhances insulin-like growth factor-II (IGF-II) action on steroidogenesis in human granulosa cells. Journal of Clinical Endocrinology and Metabolism 199478 1265-1267.

Received 24 February 2000

Accepted 7 September 2000 